\title{
From Normative Pluralism to a Unified Legal System in Afghanistan?
}

\author{
Siavash RAHBARI* \\ International Development Law Organization
}

\begin{abstract}
This paper suggests that Afghanistan's fractured plural legal system is beginning to show some signs of cohesion and coherence. I briefly describe the aspiration set out in the Constitution of Afghanistan and its mandate to legislators and jurists to harmonize Islamic jurisprudence, the principles of justice, customary norms, and international treaty obligations. I then discuss some of the setbacks, obstacles, and more recent progress that have shaped the journey towards that aspiration. The paper specifically addresses the role of lawyers as they learn to navigate the more coherent landscape and the development and impact of a nascent adversarial system. Finally, the paper addresses the role of customary dispute resolution and the bifurcated legal-education system, and their impact on the development of a more unified legal system.
\end{abstract}

Keywords: Afghanistan, normative pluralism, defence bar, customary dispute resolution

\section{INTRODUCTION}

The continued development of rule of law in Afghanistan faces serious obstacles. Clearly, the instability and insecurity caused by an internationalized non-international armed conflict and narcoterrorism continue to pose existential threats to the Afghan state. For those working on peace and political participation, the discussions about the development of the rule of law in the current political context are sometimes incomprehensible, because they appear to ignore the fact that Afghanistan is not a post-conflict nation and a significant portion of the population live under the rule of the Taliban. ${ }^{1}$ For good governance professionals, these discussions must focus on the rampant corruption and its impact on both on the rule of law and the ongoing conflict. ${ }^{2}$

As a development professional who has been working on access to justice, human rights, and legal education in Afghanistan since 2010, I recognize that armed conflict and corruption

\footnotetext{
* Coordinator for Afghanistan for the International Development Law Organization (IDLO). Previously the Rule of Law Specialist for The Asia Foundation-Afghanistan, Technical Adviser to Open Society Afghanistan, and Program Manager at the International Legal Foundation (ILF), J.D. University of Texas. Any statements of fact, opinion, or analysis expressed herein are entirely those of the author and are not attributable to IDLO or any former employer. Correspondence to Siavash Rahbari, Via Gian Domenico Romagnosi, 20 Roma, Roma, 00196, Italy. E-mail address: sia.rahbari@gmail.com.

1. Conversations with Graeme Smith, June 2018. Indeed, this paper does not delve into a discussion of the Taliban's administration of justice, although a significant portion of the population live under their rule.
}

2. See Integrity Watch (2018). 
remain fundamental challenges. However, the association between security, corruption, and justice is convoluted and dynamic, and rule-of-law development is not simply a victim of the conflict and corruption. It can also be a force that helps to tame both of these challenges. Nor is it the case that peace and reduced corruption will suddenly eliminate all of the challenges to rule of law in Afghanistan.

One such challenge is normative pluralism - the existence of a varied set of sources for overlapping and sometimes contradictory norms, rules, regulations, and laws - which is only partially associated with the ongoing conflict and corruption. This pluralism is well documented and the source of a great deal of thought and often consternation for the development community. ${ }^{3}$ The discussion usually revolves around a fractured legal landscape, made up of state laws, Islamic jurisprudence, broader notions of sharia, and customary (informal, traditional) structures. Even for thoughtful observers, highlighting these fractures can sometimes lead to an inability to see a greater whole. For others, the fetishizing of the Afghan or Islamic nature of some of these fractures can obscure the parallels and similarities they share with other nations as they developed their legal systems. ${ }^{4}$ This is not simply a case of not seeing the forest for the trees, but rather a notion that, because these saplings have strange names and look a little different from our trees back home, this can never become be a forest. Anyone trying to foster the legal system in Afghanistan is stuck between defending development interventions against ill-informed notions that such interventions are supporting "oppressive sharia" and verbose academic criticisms that consider the very concept of the rule of law to be imperialistic. ${ }^{6}$

It is true that the constitutionally mandated relationship between state laws, international obligations, Islamic principles, and customary norms have indeed presented serious challenges to legislators and the courts. These challenges are exacerbated by a bifurcated legaleducation system that produces legal professionals using a "law" track and a "sharia" track and consequently creates an instant division between legal professionals. On top of this, the system has had to reckon with the influence, demands, and sometimes misunderstandings of international donors, commentators, activists, and development workers.

Over the last eight years, I have reviewed hundreds of cases, court filings, and draft legislation in Afghanistan and maintain close ties with defence lawyers, prosecutors, judges, and technocrats in the justice and law-enforcement sector. The view from the ground indicates that, out of the churn of traditions, systems, and actors, one can begin to see the vague outlines of a distinctly Afghan legal system being formed-one that could deliver many elements of the rule of law. In this paper, I will discuss how recent legislation show more sophisticated attempts at synthesizing the various normative traditions and sources of law in the Constitution. Also, courts have become more likely to use these laws and are generally more pragmatic and organized. There appears to be real progress in creating a realistic and workable relationship between the formal and customary systems. There has even been some movement in the legal-education sector towards providing a more complete education that

\footnotetext{
3. See e.g. Wardak (2004); Daxner (2011); Choudhury (2017); Swenson (2017).

4. E.g. insisting that Islamic law is somehow very different from the extensive religious influence on the laws of their own countries.

5. See e.g. Meeting Minutes (2017); Kessler \& Lee (2016); Otto (2008).

6. De Lauri (2010).
} 
can produce flexible legal professionals who understand the varied normative traditions that make up the Afghan justice and dispute-resolution landscape.

This is not to say that the rule of law or legal system in Afghanistan is already wholly coherent, vibrant, and simply misunderstood. ${ }^{7}$ The process of synthesis has just begun and, just like in other societies, even after it has substantially emerged, it will be endlessly adjusted and refined. However, for the clever legal professional, there is a coherent-enough landscape that, while fraught and fractured, is navigable with the proper skills. This is especially the case for defence lawyers who are both the cause and the effect of a more adversarial system. The primary goal of these defence lawyers is to meet the needs of their clients. ${ }^{8}$ This pragmatic approach has allowed them to not only embrace the prevalent normative pluralism, but also to begin to weave the different strands together into the outlines of what a holistic and idiosyncratically Afghan legal system will look like.

\section{THE CONSTITUTIONAL MANDATE}

It is now almost cliché to describe Afghan law as a combination of Islamic law, state legislation, and customary law. ${ }^{9}$ Still, for the sake of clarity, it is important to summarize the nature of this combination and how it comes about, before outlining its emerging coherence and how this coherence is used in practice.

The 2004 Constitution of Afghanistan establishes an independent republic ${ }^{10}$ with Islam as its state religion, ${ }^{11}$ and further declares that no law passed by the state is allowed to "contravene the tenets and provisions" of Islam. ${ }^{12}$ It compels courts to apply the Constitution and laws of the state to decide matters and, where the law is silent, judges should decide a matter in a just manner while remaining within the bounds of the Constitution and in pursuance of Hanafi jurisprudence. ${ }^{13}$ In similar circumstances, for members of the Shia branch of Islam, the courts should apply Shia jurisprudence. ${ }^{14}$ Finally, it binds the state to observe the United Nation's Charter, Universal Declaration of Human Rights, and other international treaties and agreements that it has joined. ${ }^{15}$

The Civil Code, which predates the current Constitution, does not permit judges to apply their own interpretation (religious or otherwise) if there is an applicable law but, if there is no such law, instructs judges to decide cases using the general principles of Hanafi jurisprudence. ${ }^{16}$ If judges cannot find guidance in Hanafi jurisprudence, they are to resort to common custom, so long as that custom does not violate the law or the "principles of justice."17

7. See Cook-Miligan (2013).

8. This is not a comment on how dedicated and altruistic defence lawyers are. Rather, it is simply their job to represent their clients and those lawyers who have the most satisfied clients are the most successful in civil society circles and especially in the private market.

9. Yassari \& Saboory (2010); Choudhury, supra note 3; Khan (2015).

10. 2004 Constitution of Afghanistan, Art. 1.

11. Ibid., Art. 2.

12. Ibid., Art. 3.

13. Ibid., Art. 130.

14. Ibid., Art. 131.

15. Ibid., Art. 7.

16. Civil Code, Official Gazette No. 353, 5 January 1977, Art. 1.

17. Ibid., Art. 2. 
So, in principle, the Constitution and the Civil Code integrate the law, Islamic jurisprudence, and common custom in a manner eminently reasonable for a nation with a state religion. Thus, the legal pluralism of Afghanistan is not just an uncontrolled emergent reality, but also an articulated and deliberate challenge to Afghan legislators and courts. Legislators are given the task of drafting statutes that adhere to all of the sources of law stated above, while also taking into consideration the economic, security, and political impact of their laws. Generally, courts are then supposed to trust the legislators and only refer to the other normative sources when the law is absent.

This has been, and will continue to be, a complicated aspiration-as in all constitutional democracies. The expertise required to meet this challenge would be daunting for any society. In 2004, Afghanistan had very little of this capacity, and it continues to struggle to build it. Progress has been slow and unsteady. Still there have been improvements that point the way forward or, at least, better define the challenge.

\subsection{Legislation}

Afghanistan's legislative process is complex, and its details are outside the scope of this paper. In short, a draft law should originate either from an executive bureaucracy — such as a ministry or directorate - or the Parliament. The Taqnin Department of the Ministry of Justice $^{18}$ then checks the proposed legislation against other laws, seeks comment from appropriate stakeholders, and brings the text into the appropriate format. It is then debated, amended, and passed (or rejected) by Parliament or decreed by the president until such time that Parliament can take it up. ${ }^{19}$

However, partly due to ongoing dysfunction and the failure to hold elections, Parliament is incapable of fulfilling its constitutional mandate. As a result, the legislative process has been and continues to be driven almost exclusively by the executive branch with input from the judiciary, and any law that is even remotely controversial is decreed by President Ashraf Ghani (and President Hamid Karzai before him) rather than put up for a parliamentary vote.

The process of passing legislation continues to be a clear example of Afghanistan's difficulty with certain elements of the rule of law. As compared to a few years ago, however, the current legal landscape in the criminal-law context is increasingly coherent and comprehensible, thanks to the new Criminal Procedure Code and the new Penal Code. This is a significant accomplishment considering early setbacks and the politically sensitive topics that these codes address.

\subsubsection{The ICPC: An Early Setback}

In 1965, Afghanistan enacted a criminal procedural code modelled closely on the Egyptian code of the time. Egypt had similarities in culture, especially in rural areas, and Cairo provided legal scholars at the invitation of Kabul to help with the authoring of a structured, detailed, and comprehensive code with 500 articles covering criminal procedure. ${ }^{20}$ The Taqnin Department, in consultation with other justice institutions, made substantial changes to the code in 1974, to

18. The Taqnin is the legislative drafting department of the Ministry of Justice; it chairs legislative drafting sessions and assures that laws remain consistent.

19. 2004 Constitution of Afghanistan, Arts 79, 90, 94, 95, 97.

20. Jupp (2013). 
bring it closer into line with the Afghan context. ${ }^{21}$ The 1974 Criminal Procedure Code (1974 CPC) was one of the few legal codes that remained officially untouched by the governments that followed ${ }^{22}$ and was very familiar to Afghan jurists and legal academics. ${ }^{23}$

Sadly, this information somehow escaped the attention of those tasked with leading justice reform and rule-of-law development in Afghanistan. These legal experts set about creating a new Interim Criminal Procedure Code (ICPC) as one of their first assignments in the aftermath of the US invasion that removed the Taliban government in $2001 .^{24}$

The adoption, in 2004, of the ICPC faced vociferous opposition by veteran lawyers working for the Taqnin Department. They objected to replacing a long-established code with an interim law one-fifth its size and filled with foreign concepts. They went so far as to lobby parliamentarians against its passage. Most commentators and Afghan officials now claim that the ICPC was issued only because President Karzai was told that funding for justice projects might otherwise be withdrawn. ${ }^{25}$

A 2011 document entitled Italy and the Rebirth of Afghanistan's Justice System explains that the ICPC was a priority considering that "violations of human rights are the tragic consequence of the abuse of power, and that the best manner to prevent and eliminate such abuse lies in the discipline of criminal procedure." ${ }^{, 26}$ The authors claimed to understand the challenges Afghanistan faced ${ }^{27}$ but, seven years later, they still failed to mention the existence of the 1974 CPC or discuss why that law was not amended, rather than creating a new code. Instead, they claimed that the ICPC "despite its brevity and simplicity, contained all of the basic principles enunciated in the United Nations conventions for the protection of human rights in legal proceedings." 28

The ICPC was undoubtedly a mistake. Its distribution to judges and prosecutors across the nation took three years. Despite the large sums spent to draft it, ${ }^{29}$ significant portions of the ICPC were simply copied from its Italian counterpart. ${ }^{30}$ It introduced legal concepts, such as judicial police, that were (and remain) foreign to the Afghan system. ${ }^{31}$ In violation of international law, it allowed for an extended period of pre-trial detention under the authority of the prosecutor. ${ }^{32}$ It lacked specific procedures on how the legality of detention should be assessed at the primary court level or how accused persons could challenge their pre-trial detention. ${ }^{33}$ It provided only cursory guidance on evidentiary rules, such as what qualifies as

21. Arts 1-144 covering discovery and investigation of crime were amended.

22. The Taliban did not implement the 1974 CPC, but they did not repeal it. The self-declared Islamic Emirate mostly ignored the legal traditions fostered in the decades before their rule, considering them un-Islamic.

23. Jupp, supra note 20, p. 57.

24. Perathoner (2011), p. 12; Hartmann \& Klonowiecka-Milart (2011), p. 275.

25. Jupp, supra note 20, p. 60.

26. Perathoner, supra note 24, p. 13.

27. Ibid., p. 13. The document also explains that Italy had been a supporter of rule of law in Afghanistan for some time, "by its offer of hospitality in 1973 to King Mohammad Zahir Shah, who had been deposed by his cousin Daoud, a Soviet puppet."

28. Ibid., p. 14.

29. In several meetings, Afghan officials have claimed that at least 2 million dollars were spent during the drafting process.

30. Hartmann \& Klonowiecka-Milart, supra note 24.

31. Ibid., p. 280.

32. Ibid.

33. Jupp, supra note 20, pp. 66-7. 
evidence and how evidence is to be introduced. It did not specifically identify the codes it was replacing, thereby creating confusion on what laws apply in different procedural instances. ${ }^{34}$ This left legal professionals with the ability to pick and choose which procedural rules to follow from the $1974 \mathrm{CPC}$, the ICPC, and several other laws. ${ }^{35}$ As such, the ICPC was not only useless, but harmful to the coherence of the legal system in Afghanistan. ${ }^{36}$

It should also be noted that some of the criticism of the ICPC was just as misguided as the intervention itself. Foreign commentators criticized the code for "creating" uniform and centralized legal norms in a society that was used to informal and tribal systems and argued that Afghans may not need or want such laws. ${ }^{37}$ Just as the authors of the ICPC, these criticisms failed to even mention the 1974 CPC, and instead pursued a narrative that presented Afghanistan as so exceptional a country that it would not benefit from a more uniform legal system or even, simply, a criminal procedure code.

\subsubsection{The New CPC and Penal Code: Signs of Progress}

Beginning in 2006, a Criminal Law Reform Working Group (CLRWG) was established at the behest of the Taqnin Department. This group is made up of representatives from several state institutions, international organizations, and civil society organizations, ${ }^{38}$ and began working on a new criminal procedure code in 2007. In 2013, they completed the task and were able to unify criminal procedure under one law.

The CLRWG was also responsible for the creation of the new 2017 Penal Code and offered a model of inclusive and patient co-operation that was used in other venues. The same methodology resulted in the drafting and passage of the Anti-Torture Law, and a draft Reconciliation Law (discussed further below) that creates links between the state and customary dispute-resolution bodies. This co-operative and consultative model is also being considered for future legislative efforts such as a new Family Law, Civil Code, and Labour Law.

The main practical advantage of the 2013 CPC and the 2017 Penal Code are their comprehensiveness. These codes have incorporated, unified, and superseded an unmanageable number of free-standing criminal and procedural laws, and criminal offences tucked into other types of laws. These are detailed codes, specifically created for Afghanistan rather than transplants. Additionally, they represent a serious effort to deliver on the complicated aspirations set forth by the Constitution. The CPC provides for a comprehensive set of rights for both the accused and the victims of crimes. The Penal Code reduces sentences dramatically, and both codes encourage the use of alternatives to incarceration.

34. Art. 98 of the ICPC states: "Upon entry of the Presidential decree, any existing laws and decrees contrary to the provisions of this code are abrogated." This lack of specificity left quite a bit of interpretation about what was "contrary" to the provisions of the ICPC and allowed many jurists to continue to use the 1974 CPC and other laws.

35. Such as the 1967 Law on Attorney General's Office and the 2005 Law on Organization and Jurisdiction of Courts.

36. Many lawyers who practised in these years note that they would try to figure out each individual judge's background and training, then cite to the whatever procedural source they preferred. These defence lawyers would always cite the ICPC, because their international mentors and supervisors insisted on it (since it was the law), but then they would go on to cite the 1974 CPC, 1967 Law on Attorney General's Office, Islamic sources, and whatever else could fill in the gaps left by the ICPC.

37. International Crisis Group (2010); Ahmed (2005).

38. The Supreme Court, the Attorney General's Office, Afghan Independent Human Rights Commission, Afghanistan Independent Bar Association, EUPOL, GIZ, UNDP, UNODC, USAID, INL, etc. 
Neither the CPC nor the Penal Code is a perfect piece of legislation. Among other matters, the CPC allows pre-trial detention periods that human rights advocates find objectionable, and its approach on statutes of limitation exacerbates Afghanistan's problem with a profusion of in absentia cases. ${ }^{39}$ Similarly, the Penal Code raises many issues of concern to the international community, such as allowing judges to order accused women and even victims to undergo intrusive and humiliating hymen examinations. ${ }^{40}$

Still, even bearing in mind these shortcomings, these laws signify a concerted effort by the drafters to consider general principles of justice, Islamic jurisprudence, international human rights obligations, customs, and-more often than not-the logistical and political realities of Afghanistan. These realities, rather than an adherence to regressive interpretations of sharia or pashtunwali, are at the root of some of the problematic issues in these codes. For example, the CPC's pre-trial detention periods remain too long, because prosecutors in farflung districts complained that they could not meet shorter deadlines due to the distances they have to travel to get to functioning courts. ${ }^{41}$ The problems with in absentia cases are partly due to a desire to encourage law-enforcement authorities to investigate crimes in a timely manner and the courts' desire to reduce their case-load. ${ }^{42}$

\subsubsection{The Penal Code and Hudud: A Pragmatic Punt}

Practical realities will continue to present challenges as legislators and policy-makers try to balance aspirations against the limitations and needs of practitioners and law-enforcement professionals. However, there are topics that are solely problematic because of the conflict between the normative systems involved. These matters underline the fact that the Constitution's aspirations are lofty and that rule of law in Afghanistan remains fragile and will still need time and patience to fully develop, even if peace and greater security are established.

One of the most difficult areas is how the justice system deals with hudud crimes, which are an important element of Islamic legal doctrine and are seemingly difficult to reconcile with central tenets of international human rights doctrine. Hudud ${ }^{43}$ crimes are a complex legal and theological topic but, in short, these crimes-theft, illicit sexual relations, making unproven allegations of illicit sexual relations, drinking intoxicants, highway robbery, and possibly apostasy ${ }^{44}$-are considered transgressions against the rights of God. Each carries a

39. Criminal Procedure Code, Official Gazette No. 1132, 5 May 2013, Art. 209. The latter problem also results in a waste of legal aid resources, because judges are empowered to assign defence lawyers to these types of cases when they could be representing individuals in detention.

40. 2017 Penal Code, Official Gazette No. 1260, 15 May 2017, Art. 640.

41. They also note that investigations in the districts can take longer because of lack of roads or insecurity. There are those for whom this excuse is justified and other law-enforcement institutions that abuse these clauses to, for example, coerce detainees into confessions.

42. Conversations with Ashraf Rasooli, Senior Adviser to the Minister of Justice, June 2018. Similarly, while the Penal Code makes it a criminal offence for the police or prosecution to order a hymen examination, the judiciary insisted that the government had no right to limit a judge's ability to do so. These arguments were not based on sharia or customs, but rather on a misguided but ardent appeal to judicial independence.

43. “'Hudud Allah' in the Qur' an is a broad concept which is neither confined to punishment nor to a legal framework but provides a comprehensive set of guidelines on moral, legal, and religious themes." Kamali (1998), p. 204.

44. Ibid., p. 214. Whether apostasy is a hudud crime has been in dispute since the early days of Islam; Definition of hudud is from Oxford Islamic Studies Online (2018). 
punishment designated in the Quran or hadith that range from flogging and amputation to death by stoning.

Regardless of the punishment levied, criminalizing apostasy (especially conversion) is a violation of human rights norms enshrined in conventions Afghanistan is a party to, ${ }^{45}$ and criminalizing adultery is at minimum suspect. ${ }^{46}$ Regardless of their legitimacy as crimes, all hudud sentences represent a continuum of corporeal and capital punishments that are prohibited under international human rights law. ${ }^{47}$

In Afghanistan, Article 1 of the 1976 Penal Code addressed this distinction by asserting that the crimes and punishments in the code solely describe infractions that come under the jurisdiction of the state. These "taziri" crimes disturb the peace of society and infringe on the rights of the sovereign, and the corresponding punishment is at the discretion of judge or the rulers of the state. ${ }^{48}$ It mandates that hudud crimes should be dealt with by the courts using Hanafi jurisprudence. ${ }^{49}$ Still, the 1976 Penal Code codifies crimes such as consumption of alcohol or theft and their corresponding state punishments (usually incarceration). ${ }^{50}$ The code specifies again that the taziri version of the crime and its corresponding punishment should be used only when the hudud version cannot be proven or is otherwise dropped, ${ }^{51}$ though it never explains anything else about these hudud offences.

In this fashion, the 1976 Penal Code avoided spelling out hudud punishments. From a human rights perspective, this could be considered a strength, because the state does not explicitly endorse these punishments. It may also be argued that, under the 2004 and 1964 Constitutions, the courts are obligated to use codified law before resorting to Hanafi jurisprudence and, since there are laws that address these crimes, a court should use the codified punishments instead. $^{52}$

However, a less strained interpretation of the 1976 Penal Code — and the one most Afghan legal experts consider to be accurate-recognizes that Article 1 incorporates hudud crimes into the criminal justice system. This is reaffirmed each time an article notes that the taziri punishment is a substitute for the hudud punishment when the latter cannot be applied. The explanation of the punishment need not be explicit, since they are well known, even among many illiterate laypersons. ${ }^{53}$

With this in mind, and recognizing the sensitivity of the subject, the Ministry of Justice established a working group in 2013 to deal with hudud crimes in the 2017 Penal Code that was under revision by the CLRWG. From the outset, the hudud working group acknowledged that omitting Article 1 of the 1976 Penal Code from a new penal code would be a

45. UN General Assembly (1948), Art. 18; UN General Assembly (1966), Art. 18.

46. UN News (2012). It should be noted that adultery is still illegal in several US states, such as Idaho, were it is a felony. Idaho Statutes (2018), p. 966.

47. UN General Assembly (1966), supra note 45, Arts 6-7; Office of the United Nations High Commissioner for Human Rights (2018).

48. The Ottoman Penal Code of 1858 also only dealt with taziri crimes and never even mentioned hudud crimes, although it does take note of qisas and diat; see the Imperial Ottoman Penal Code (1913).

49. 1976 Penal Code, Official Gazette No. 347, 7 October 1976, Art. 1.

50. See e.g. Arts 349 on alcohol consumption, Art. 427 on adultery, and Art. 447 on robbery.

51. See Arts 426 and 447 of the 1976 Penal Code, supra note 49. This is not the case for consumption of alcohol in Art. 349, ibid.

52. 1964 Constitution of Afghanistan, Art. 102.

53. Conversations with Sayed Ashraf Mozafari, Professor of Criminal Procedure at the American University of Afghanistan, June 2018. 
non-starter, politically, because conservative politicians and the clergy would view it as an attack on Islamic principles. They were also aware that, historically, the main safeguards against the use of hudud punishments were the high burden of proof required to establish guilt and the admonition to jurists to "ward off the hudud by ambiguities (shubuhāt)." former is famously exemplified by the Quranic rule that, in order to prove adultery, four male witnesses of sterling reputation must testify to having seen the specific act of intercourse. ${ }^{55}$ An example of the latter is that a majority of scholars do not consider pregnancy proof of adultery, even if the husband was away for years. ${ }^{56}$ Partly as a result of these safeguards, there was only one recorded instance of stoning in Istanbul in over 400 years of Ottoman Rule. $^{57}$

The working group also believed that, while the competence and education of judges and prosecutors were steadily increasing, it would still take some time before the justice system is staffed exclusively by well-educated professionals. ${ }^{58}$ Most Afghans know the punishments associated with hudud, but few understand the less salacious, more technical, and often strict evidentiary rules. ${ }^{59} \mathrm{With}$ this in mind, the working group decided to codify the hudud to give clear guidance to judges that would meet Hanafi jurisprudence procedural and evidentiary requirements.

In addition, the working group recognized the danger of false witnesses, forced confessions, and a dearth of judges who could formulate a theory of a case that could cleverly avoid hudud punishments. So, in addition to codifying the evidentiary procedures, many members of the working group insisted that (unlike in traditional interpretations) all hudud cases should be subject to the appeals process of the Afghan justice system. ${ }^{60}$

However, for Afghan and international human rights advocates, the idea that the official Penal Code of Afghanistan would include stoning as a punishment for adultery was completely unacceptable. It is unclear how well these activists understood the motives of the working group, and it appears that they did not appreciate that hudud crimes were already incorporated into the 1976 Penal Code. ${ }^{61}$ Still, even with greater insight into the motives of the working group, it may have been difficult for them to trust the justice system in Afghanistan. ${ }^{62}$ So, following a short but effective effort by Human Rights Watch, the hudud working group was disbanded.

The new Penal Code takes a similar approach to hudud crimes as the 1976 code, meaning that hudud punishments continue to be a viable option under Afghan law but are wholly uncodified. The main difference between the codes is the reduced sentences for the taziri

54. Brown (2017), p. 11; see also Rabb (2010).

55. Quran, 24:2, 4, 2:15. Famously, the eyewitnesses must have seen the penis enter the vagina like a kohl stick entering a kohl container. Yorke \& Nazir (2017), p. 4.

56. Brown, supra note 54, p. 13.

57. Zarinebaf (1998), p. 304.

58. Veteran judges and prosecutors, especially those in the districts, were not necessarily university graduates and, while training programmes have tried to improve their knowledge, it is difficult to change habits acquired over a lifetime of work.

59. The $1974 \mathrm{CPC}$ did not address hudud procedure.

60. Interview with Ruhollah Qarizada, President of AIBA, June 2018.

61. Human Rights Watch (2013).

62. Such a lack of trust was well founded, considering that, only a few years earlier, it took immense international pressure to create the legal fiction necessary for the release of a man facing the death penalty for apostasy. See Wafa \& Rohde (2006). 
versions of the crimes. For instance, the consumption of alcohol no longer carries any prison term, and the punishment for fornication changed from a minimum of five years to a maximum of two years of incarceration. ${ }^{63}$

For the development of rule of law in Afghanistan, this episode raises many questions. What is worse for rule of law-failing to codify important and potentially dangerous criminal laws, or an explicit recognition of punishments that fly in the face of human rights conventions? Would codification lead to an arrest in the development or evolution of how Afghans interpret Islamic norms? Could a nearly impossible standard of proof serve as an alternative to abolishment of cruel punishments? Is strict adherence to human rights conventions essential to the rule of law?

Separately from these issues, both the human rights advocates and the working group were partially (and justifiably) motivated by a lack of trust. The working group lacked faith in judges, and the human rights advocates lacked faith in both the legislators and the judges. However, the reduction in the taziri sentences and interviews with members of the working group reveal that the drafters were indeed striving for hudud avoidance. Also, the dearth of hudud sentences by the state courts in the last decade indicates that the judiciary is not clamouring for these harsh punishments.

Both the issues raised by this episode and the trust deficit (including a suspicion by the devout that the elite will abandon Islamic principles) are not easily resolved by ad hoc ruleof-law development interventions or outside experts. Neither short-term training of jurists nor a few academic conferences will be able to tackle these complicated issues or dispel the distrust on all sides. ${ }^{64}$ However, the new Penal Code (and other recent legislation) also demonstrates that progress is being made. Further progress will require trusted domestic experts that will be created through long-term investment in a legal-education system that teaches all the elements of the Afghan legal system. It will also require better data for these experts to analyze and a robust adversarial system, where legal professionals can educate each other through the daily practice of law.

\subsection{The Courts}

As noted above, the Constitution articulates a challenge to Afghan legislators and courts to understand and apply the principles of justice and Islam, Hanafi and (for limited subjects) Shia jurisprudence, Afghanistan's international obligations, and their own common customs. The courts are mandated to trust that the legislators have fulfilled their duty and only refer to the other normative sources when the law is absent or unclear. ${ }^{65}$

This has been a difficult directive for the courts. First, the laws themselves were a hodgepodge of codes created by radically different governments, including a constitutional monarchy, a unitary Marxist-Leninist one-party socialist republic, an Islamic Emirate, and the current Western-backed Islamic democratic republic, much influenced by international governments that provide substantial financial support. In the criminal-law context, by 2012, there were two different criminal procedure codes, since the ICPC failed to fully replace the 1974 CPC. There

63. 1976 Penal Code, Arts 24, 426; 2017 Penal Code, Arts 644, 684. The new Penal Code also makes a crucial change by clearly separating adultery (zina) from rape-a long-awaited and much-needed development.

64. A peace process will further highlight this distrust, since human rights advocates and progressively minded Afghans suspect that peace will come at the price of incorporating some elements of the Taliban's interpretation of Islamic law into the Afghan justice system.

65. The Constitution of Afghanistan, Arts 130, 131. 
were also a number of codes related to criminal matters and even some regulations that attach criminal responsibility to behaviour. ${ }^{66}$ These laws very much reflected the governments that passed them. For example, the Law on Crimes against Internal and External Security, approved by the Revolutionary Council of the Democratic Republic of Afghanistan in 1987, included crimes such as "propaganda against the government" and "hatching plots for winning seats in the government." 67 This law was regularly used to prosecute insurgents and security offences until the new Penal Code came into effect in February of 2018.

Exacerbating this problem was the fact that many judges, prosecutors, and lawyers did not have access to these codes and many others had outdated copies that had not been updated after amendments were passed. In a 2006 survey, 55\% of judges had no access to textbooks on the law, procedures, and practice and $36 \%$ did not have sufficient access to statutes and regulations. ${ }^{68}$ The same survey showed that more than a third of judges had only a highschool-level education. ${ }^{69}$ Another study two years later showed similar education gaps for prosecutors, Ministry of Justice officials, and defence lawyers. ${ }^{70}$ However, even those judges who had tertiary degrees were unfamiliar with state laws, because they were predominately graduates of the Sharia Faculty - one of two university departments that create legal professionals (as discussed in Section 3 below). ${ }^{71}$

By 2010, the courts were still regularly failing to cite state laws in their judgments. Even prosecutors and defence lawyers who were trained in the law were inconsistent in their use of specific articles and statutes, because they found that it only confused many judges. For example, indictments would refer to theft, but not cite the specific Penal Code articles. At other times, a case would be tried under a general law such as the Law on Crimes against Internal and External Security without a specifically cited article. ${ }^{72}$ In response, defence lawyers would often use the same terms and phrases in their defence statements to maintain consistency. Judges would then often rule using Article 130 of the Constitution, ${ }^{73}$ again without any citation to a law, but instead to vague Hanafi jurisprudence, if that. Beyond the obvious failure to adhere to the constitutional mandate, this behaviour made case management, case tracking, and supervision difficult, since identifying specific criminal violations is an important piece of metadata.

To meet this challenge, development interventions concentrated on massive training efforts. $^{74}$ This was a reasonable decision, since it was the one advocated by local experts and preferred by state institutions. It was also difficult for the state to simply fire its less-educated

66. E.g. the Legal Aid Regulation made it a crime for legal aid providers to provide legal services for a fee. Legal Aid Regulation of Afghanistan, Art. 8.

67. Law on Crimes Against Internal and External Security, Decree No. 153, October 1987, Arts 1(c), 7.

68. Armytage (2007), p. 196; USAID (2005), p. 27. This statistic was often inflated to two-thirds of the judiciary in several reports, e.g. by the UN and US Congressional Researchers. See UN General Assembly (2006); Wyler \& Katzman (2010).

69. Armytage, supra note 68, p. 190.

70. Taylor (2008).

71. Armytage, supra note 68, p. 190.

72. Criminal Cases from 2010 to 2013 (on file with author).

73. Art. 130 of the 2004 Constitution states: "In cases under consideration, the courts shall apply provisions of this Constitution as well as other laws. If there is no provision in the Constitution or other laws about a case, the courts shall, in pursuance of Hanafi jurisprudence, and, within the limits set by this Constitution, rule in a way that attains justice in the best manner."

74. For a summary of these interventions, see Swenson, supra note 3. 
legal professionals, while also trying to ramp up hiring to meet the needs of the country. ${ }^{75}$ Finally, other interventions, such as imposing international mentors to shore up supervision standards, ran up against sovereignty issues for state organs and logistical issues outside of a few urban centres.

By 2012, short-term training of previously under-educated legal professionals who were used to operating without oversight or complex procedural systems had less of an impact than donors and implementing agencies had hoped for. Research suggested that this was partly due to practical obstacles such as lack of resources, security issues, lack of infrastructure, and lack of time. A quarter of respondents simply answered: "Other reasons."76

This other reason may very well include the impact of habitual behaviour. Often, in conversations with judges and prosecutors who had recently attended training and yet continued to work as before, the excuse was simply that this was how they had done it for many years. ${ }^{77}$ Legal professionals should not be expected to be able to change lifelong habits after just a few days or even weeks of training. Other implementers, speaking specifically about the lack of impact on the judiciary, suggested that this was the logical outcome when there is no political will, and that real change would take generations. ${ }^{78}$

Many of these worries reflected a continued belief that the public perception of courts was quite low. However, between 2008 and 2012, the average percentage of Afghans who agreed that the state courts were "fair and trusted" was 56\% and the average between 2013 and 2017 was $63 \%$ (which is also the percentage for the 2017 survey). ${ }^{79}$ As public opinion polls are notoriously difficult to conduct in Afghanistan, a better measure of the courts' improvement may be to simply review their output. Indictments, lawsuits, motions, defence statements, and judgments are now almost always citing specific articles in both civil and criminal cases and for both material and procedural purposes, while the use of Article 130 to issue judgments and sentences has reduced dramatically. ${ }^{80}$ This reflects not only a court system that has shown an ability to change, but one that is less likely to be arbitrary, since it is following the law.

This incremental progress cannot be the result of better logistics, greater security, or a reduction in corruption, since none of these things has occurred. Judges still face problems accessing simple office supplies while case-loads and case scheduling continue to be difficult. The civil war continues to rage on unabated, ${ }^{81}$ and Afghanistan is still suffering from stratospheric levels of corruption. ${ }^{82}$

75. Though often touted their progress on that front. See Supreme Court of the Islamic Republic of Afghanistan (2012).

76. Taylor, supra note 70, p. 23.

77. Rasooli, supra note 42.

78. USAID (2012), p. 10.

79. The Asia Foundation (2018), Survey of the Afghan People 2012-2017. It should be noted that, as compared to shuras/jirgas and the Huquq Department of the Ministry of Justice, the state courts remain much less well respected. However, it is important to remember that the former venues usually result in a negotiated outcome, meaning the parties are reasonably satisfied with the result. If a matter is contentious enough to validate a visit to the state courts, it is likely more acrimonious and will often leave at least one party dissatisfied.

80. Mozafari, supra note 53.

81. The Asia Foundation (2017); UN Assistance Mission in Afghanistan (2018).

82. Transparency International Secretariat (2018). 
There could be several reasons for this development. Training may have improved somewhat, as training organizations have gained greater experience. Another factor may be the process of creating case-management systems that require legal professionals to be precise in the mundane task of filing a case. ${ }^{83}$ Over time, turnover has led to more young professionals being hired. These new arrivals have developed better habits and have benefitted from the changes that have already been made to the legal-education system. Finally, a major reason for change is the integration of defence lawyers into the courtroom and a shift to a more adversarial system.

\subsection{Defence Lawyers}

One of the most dramatic developments in the Afghan legal system since 2001 has been the creation, essentially from scratch, of the private legal market and the defence bar. This shift has resulted in a transformation towards an adversarial system, and it appears for now that the legal system will continue to progress in this direction with significant benefits accruing for the Afghan legal system in this adversarial model. Further, the relatively young and bettereducated defence lawyers have also demonstrated a robust commitment to the Afghan legal system as outlined and aspired to in the Constitution.

The right to counsel was first formally recognized in Afghanistan in the 1964 Constitution. It was reaffirmed in the Constitutions of 1976, 1987, and 1990, and finally under Article 31 of the current Constitution. ${ }^{84}$ However, until the fall of the Taliban, legal services were mostly limited to scribes or arizeh nevis. ${ }^{85}$ This service was regulated by the Taliban under a law that remains on the books today. ${ }^{86}$ Indeed, the profession still continues, ${ }^{87}$ comprising of literate individuals, licensed by the Ministry of Justice, sitting outside the court and writing down the narration and pleas of those seeking justice within. For criminal defendants, this would often involve a family member speaking with a scribe outside to create a "defence statement" that would usually end with a plea for mercy from the judge. ${ }^{88}$

In addition to the scribes, the Supreme Court housed the Legal Aid Department, created in 1989 to provide defence services to the indigent. It was staffed by fewer than a dozen men, most of whom lacked any higher education and who provided services similar to that of the scribes. ${ }^{89}$ Defence lawyers (vakil-e modafeh) could also register separately with the Ministry

83. Several of these systems exist. One is a paper case-management system for the judiciary. The second is the national database called the Case Management System, which aims to track criminal cases beginning with the police all the way into the prison system and has recently begun tracking civil cases as well. Also, several civil society and legal aid organizations have their own systems to help them with their reporting to donors. Finally, most recently, there has been an effort to create a unified legal aid case-management system that would allow defence lawyers to have a separate system that can be cross-referenced with the national Case Management System.

84. 1964 Constitution, Art. 26; 1976 Constitution, Art. 31; 1987 Constitution, Art. 41; 1990 Constitution, Art. 41; 2004 Constitution, Art. 31.

85. Arizeh means plea or claim, and nevis means writer.

86. The Scribes Law (on file with author).

87. Such scribes exist in a variety of settings, including outside embassies or other official buildings that require documentation. They provide a very reasonably priced service that, in some circumstances, would be considered illegal practice of law.

88. Interview with Shabir Ahmad Kamawal, General Counsel of the International Legal Foundation-Afghanistan, June 2018 .

89. Smith et al. (2011). 
of Justice, though, again, their numbers were limited and the services they provided were identical to those of the scribes, though generally of slightly higher quality. ${ }^{90}$

Beginning in 2003, international and national non-governmental organizations (NGOs) began providing legal aid services to indigent accused and, soon thereafter, vulnerable groups who needed assistance to gain access to justice. These lawyers began registering with the Ministry of Justice and being trained and supervised by international mentors. ${ }^{91}$ Flush with donor funds, the salaries for these NGO defence lawyers was higher than those of the Ministry of Justice, prosecutors, judges, and law professors. Consequently, many talented legal professionals switched from these careers to sign up with the legal aid organizations, who then provided further training and educational opportunities to these new recruits. ${ }^{92}$

In its 12-year development framework for the justice sector, published in 2005, the government recognized that independent legal professionals were required for a functioning modern economy. The government also noted that there were no standards for admission to practice or any meaningful regulation or governance for the profession. ${ }^{93}$ In 2007 , the Advocates Law called for the establishment of the Afghanistan Independent Bar Association (AIBA). The inaugural general assembly in 2008 was attended by 468 advocates from across Afghanistan, the plurality of whom worked as legal aid providers for donor-funded civil society organizations. ${ }^{94}$ By early 2017, AIBA had a membership of over 3,200 licensed advocates, with only a fraction representing legal aid NGOs. ${ }^{95}$

This is an impressive pace of development, and it was partly due to a number of advantages that the defence bar enjoyed. First, because the profession was new, it was much easier to overcome the habits of the legal professionals who became defence lawyers. Thus, prosecutors and judges who were uncomfortable changing how they had been writing indictments and judicial orders were much more willing to learn about new strategies on drafting defence statements and motions. Second, the field was initially dominated by relatively small, flexible, and well-funded NGOs. These NGOs also confronted fewer of the security restrictions or sovereignty concerns that large implementing agencies who worked with the state justice institutions faced. These advantages allowed them to attract a cadre of unusually talented professionals and engage in more direct mentorship and supervision. Finally, unlike the judiciary, which was dominated by sharia graduates, and the prosecution, which was dominated by law graduates, early defence lawyers were made up of graduates from both faculties, who were encouraged to communicate and help each other. ${ }^{96}$

These talented, better-trained, and more motivated lawyers were able to carve out their place in the justice system despite serious objections from judges and prosecutors who, not unreasonably, still equated defence lawyers with scribes who sat outside the courts and peddled nothing but their literacy. This was not simply a shift from an inquisitorial system

90. Conversations with Ruhollah Qarizadeh, President of the Afghanistan Independent Bar Association, June 2018.

91. The focus of many of these organizations were on the plight of women who faced the most daunting challenges in the justice system. This, in turn, created job opportunities for women lawyers, and encouraged several women judges and prosecutors to switch careers and become defence lawyers.

92. Qarizadeh, supra note 90.

93. Government of the Islamic Republic of Afghanistan (2005), p. 8.

94. Qarizadeh, supra note 90.

95. Day \& Rahbari (2017), p. 72.

96. Qarizadeh, supra note 90. 
where the defence lawyer plays a less active role; rather, in Afghanistan, defence lawyers were previously not part of the trial process at all. Gaining access to courts and detention centres initially required a struggle for defence lawyers.

Several veteran lawyers recalled being sworn at and sometimes physically removed by judges and prosecutors. ${ }^{97}$ One lawyer described a whole trial where the judge pretended that he did not exist, by refusing to greet him or make eye contact. When he tried to read his defence statement, the judge asked the prosecutor if there was anything else and, when the prosecutor (who was a personal friend of the defence lawyer) demurred, the judge simply stood up and walked out. ${ }^{98}$

This resistance to their participation required that lawyers remain flexible in their use of legal arguments. In order to assert their right to represent their clients and be present at trial, early defence lawyers all learned to cite Article 31 of the Constitution (i.e. the right to counsel), but they also cited a hadith in which the Prophet notes that a judge may unjustly rule in favour of a more skilled or eloquent litigant. ${ }^{99}$ This hadith serves as the foundation for a majority view in Islamic jurisprudence that recognizes the right of an accused to have access to counsel. ${ }^{100}$

During the years when confusion reigned over whether and how to use the 1974 CPC versus the ICPC and when faced with sharia-educated judges who were sometimes unfamiliar with both, defence lawyers found that a successful strategy was to cite Book XV of the Majalla Al Ahkam Al Adaliyyah-an Ottoman law codifying Hanafi civil and contract law and trial procedure. While, legally, the Majalla had no standing in Afghanistan, and was not even designed for criminal procedure, it often assisted defence lawyers in their efforts to challenge evidence and testimony. ${ }^{101}$ However, the same defence statement could also include citations to international conventions, because defence lawyers were trained to do so and held accountable by their mentors. In this way, judges would at minimum have to listen to the recitation of international norms during trial. ${ }^{102}$

Still, the main objective of defence lawyers is to assist their clients, and this has led them to explore the rich legal landscape set out by the Constitution. For example, one lawyer who was a sharia graduate found himself representing a Shia man accused of sodomy. His client had ill-advisedly boasted about relations with his wife at a party with some friends. Someone who heard this story had contacted the police and made an accusation, leading the police to arrest the client. The police had several witnesses to this admission and the prosecutor had proceeded with the indictment. The client was both embarrassed and resigned to his fate when the lawyer met him at the detention centre in Kabul.

After returning to the office, the lawyer discussed the case with a Shia colleague-a graduate of the Law Faculty who still knew the complexity of Shia jurisprudence on this topic. He learned that, under Shia jurisprudence, sodomy with one's spouse may be permissible. The next day, he met with the prosecutor and the judge to discuss this. While the prosecutor dismissed the argument out of hand, the judge was intrigued but doubtful. So, the

97. Conversations with Mustafa Razm Kohestani, Advocate, December 2017.

98. Conversations with Shabir Aatashin, Advocate, December 2017.

99. Mufihun (2018).

100. Smith et al., supra note 89.

101. Qualitative Reports of the Legal Aid Organization of Afghanistan (on file with author).

102. Conversation with Najiba Rahmanzada Taj, judge and former defence lawyer, December 2017. 
lawyer asked for another meeting on the next day, then went to meet with his client. He received permission to discuss the issue with his client's mullah, who consequently confirmed with the client's wife that she had consented. The next day, in the judge's chambers, the mullah confirmed the Shia jurisprudence to the judge and the fact that the client's wife had consented. After this, the judge was perfectly content to dismiss the case based on Article 131 of the Constitution, noting that Shia matters should be decided using Shia jurisprudence. $^{103}$

Over time, many judges and even prosecutors came to not only accept the presence of defence lawyers, but rely on it. In criminal cases, many judges and prosecutors have come to request the presence of defence lawyers both because they are legally required, and because it can make dealing with defendants easier.

Judges in the civil courts are often overburdened with separation cases ${ }^{104}$ and many of the women requesting separation are illiterate, though even those who are literate and aware of their rights still lack the legal knowledge to speedily resolve their cases. Courts are crowded with desperate claimants who are lost, do not have the right paperwork, or simply do not know what remedy the court can provide. They arrive with only a piece of paper narrating their situation and an urgent need for help.

In several provinces, legal advice centres assist women with these separations. These centres are staffed by male and female lawyers and legal clinic students working side by side to determine what kind of separation would make for the strongest legal case. They explain options, compile documentation, draft claims using the appropriate laws and Islamic arguments, and give these women directions on where exactly in the court to submit their claims.

Instead of lambasting these legal aid providers for assisting women to end their marriages, as one might expect from this conservative judiciary in this conservative country, the courts were quite happy with their work because it reduced their stress of dealing with distraught women and helped streamline their case-load. In fact, chief appellate judges in several provinces invited these providers to set up small offices within the court compound to increase efficiency even further.

Scribes in Kandahar and Nangarhar complained that such centres could significantly reduce their income and asked that they be shut down. ${ }^{105}$ The chief appellate judges, in both provinces, were sympathetic to their plight. However, separated by hundreds of kilometres, several provinces, and unaware of each other, both judges made the same point to these men. Handwritten narratives produced by scribes, disorderly and devoid of any legal arguments, did not help the court run more efficiently. The judges decided that the legal aid providers were more valuable to the courts than the scribes and deserved to be cultivated and encouraged.

103. Art. 131 of the Constitution states: "The courts shall apply the Shia jurisprudence in cases involving personal matters of followers of the Shia sect in accordance with the provisions of the law."

104. While men have a right to demand divorce at any time, women can also end a marriage through a variety of legal avenues, which are usually called judicial separation/dissolution of marriage. The Civil Code of Afghanistan sets out the elements of each type of separation in Arts 176-211.

105. It should be noted that Kandahar and Nangarhar are both considered two of the most conservative provinces in Afghanistan. 
Thus, defence lawyers - a profession that was almost identical to that of the scribes themselves and initially rejected from trials by judges and prosecutors-have proven their capacity and contribution to the judicial process. Within a relatively short period of time, their value has been so well established that they can now use their halo effect to allow legal clinic students to enter the system as well and be recognized for their potential contributions.

\section{STATE AND CUSTOMARY DISPUTE RESOLUTION}

Probably of greatest interest to academics and the development community is the distinction between formal (state) and informal (traditional or customary) justice systems. The formal justice system is made up of the police, prosecution, courts, and the state-sanctioned pre-trial dispute-resolution system operated by the Huquq Department of the Ministry of Justice. ${ }^{106}$ Informal justice generally refers to various councils and fora (including "shuras" and "jirgas") where a collection of non-state actors resolve disputes using traditional norms (such as pashtunwali) ${ }^{107}$ and sometimes their interpretations of sharia or even state law. These actors derive their authority in their community by being respected for their power, wisdom, and education, and notionally strive to reach a resolution that creates lasting peace in the community. ${ }^{108}$

For the development community, an ongoing challenge has been to determine how to calibrate support between these two systems. A state justice system is a central pillar of a functioning modern state. Nevertheless, the formal Afghan system is regularly criticized for its lack of capacity, inadequate geographical reach, corruption, and lengthy processes. In contrast, and as in many other jurisdictions, informal systems can present a communitybased solution that avoids some of the downsides of formal litigation. However, informal mechanisms are not immune to corruption, can operate contrary to law, and can involve power dynamics that are harmful to vulnerable populations such as women, children, and the indigent. Organizations focused on human rights and women's rights continue to be extremely wary of the informal system. Conversely, insurgents who claim to be fighting for traditional Afghan values are frequently supportive of informal systems or consider them compatible with their own Taliban courts. ${ }^{109}$

For some time, rule-of-law development efforts in Afghanistan were criticized for focusing too much on formal justice and failing to account for and support informal mechanisms. After all, in Western countries, the use of alternative dispute resolution has been increasingly encouraged as a means to reach amicable resolutions and reduce stress on the formal justice system. ${ }^{110}$ Accusations were made that, because of their blinkered support of the formal system, donors were "condemning and marginalizing customary practices in

106. The Huquq Department of the Ministry of Justice attempts to resolve cases through settlement or reconciliation, before they move to trial. For more information, please see Ministry of Justice of the Islamic Republic of Afghanistan (2018).

107. Pashtunwali (or the way of the Pashtuns) refers to the unwritten code of values, ethics, and norms that are supposed to guide the behaviour of Pashtuns. It is often referred to as a tribal code or an ideal of honourable behaviour among Pashtuns. See Rzehak (2011).

108. Swenson, supra note 3, p. 120.

109. Conversation with Graeme Smith, June 2018.

110. Government of the Islamic Republic of Afghanistan, supra note 93, p. 11; De Lauri (2013), pp. 4-29. 
the resolution of disputes." ${ }^{111}$ Further, it is often argued that Afghans were substantially more likely to use informal mechanisms and overwhelmingly preferred to do so. ${ }^{112}$ As a result, greater efforts were initiated in 2010, to deal with the weaknesses of the informal sector. Donors and implementers as varied as UN agencies, USAID, the French Embassy, etc. attempted to train local elders on Afghan law and improve outcomes for women by increasing their access to alternative dispute resolution. ${ }^{113}$ Even the US military engaged with local informal dispute-resolution mechanisms as long as they were not affiliated with the Taliban. ${ }^{114}$

Much of the clamour for further engagement with the informal system was based on dubious data about the prevalence of its use and broader impact. An oft-cited figure that, in Afghanistan, $80 \%$ of disputes are settled through traditional justice bodies is misleading and most likely meaningless, but it became a common talking point in the development community. ${ }^{115}$ It could well be that this number is accurate or even underestimates the use of customary mechanisms, but current data do not necessarily support that assertion. In 2017, of those respondents who report using a dispute-resolution service, $43.2 \%$ said that they used a village/neighbourhood-based shura/jirga, 39.5\% used state courts, and $21.4 \%$ used the Huquq Department. ${ }^{116}$

Involving informal justice mechanisms in rule-of-law development programming was also a "damned if you do, damned if you don't" scenario, since many of these efforts were later panned as failures, because they lacked nuance or flexibility and disrupted delicate local power balances. ${ }^{117}$

In addition to being criticized by evaluators and commentators, these initiatives drew the ire of the Afghan government and justice officials, who saw them as legitimizing flawed parallel institutions and a distraction from the dire needs of the formal system. ${ }^{118}$

111. Ibid.

112. Swenson, supra note 3, p. 120.

113. See Checchi and Company Consulting, Inc. (2011); Yang (2013); UN Development Programme (2013), p. 18.

114. US Department of Defence (2012), p. 113.

115. While reviewing the literature about the prevalence of informal justice, it became clear that the foundational research and data that have been repeatedly cited for over a decade were not nearly as straightforward as one might assume considering the manner and extent to which they were cited. A 2007 UNDP report called the Afghanistan Human Development Report explained right on its very cover: "The cover design, is based on two images. The upper part of the circle showing a formal court in session represents the less than $20 \%$ of disputes that are currently settled through the state court system in Afghanistan. The larger portion below signifies the more than $80 \%$ of cases settled through traditional justice bodies." To support this claim, the report cites the 2006 Survey of the Afghan People by the Asia Foundation and Justice for All—a strategy document by the Ministry of Justice. The latter document discusses alternative dispute resolution in general terms but cites no statistics or makes any claims about its popular usage. The 2006 Survey asks respondents what they do when they have any dispute - a question that is undefined and very broad. Most people in most societies do not immediately seek out a court when facing most disputes, but rather seek ways to resolve the dispute informally, such as speaking with family and friends. Still, $20.1 \%$ of respondents to the 2006 Survey stated that they preferred to use formal government courts (the UNDP report miscites this figure as $16 \%$ ), while only $16.2 \%$ preferred a local shura. It is true that all of the answer options that are not formal courts, including local elders, tribal leaders, mullahs, none, and other, add up to $80 \%$, but it is unclear how these options can be called traditional justice bodies. Another original source of these types of statistics is a 2008 Oxfam report called "Community Peacebuilding in Afghanistan" that similarly fails to define "dispute" and shows its own chart (Figure 3) that the most popular avenue for a dispute-resolution "mechanism" was the police. Still, it goes on in the text to insist that "overall the single most popular mechanism for the resolution of disputes is community or tribal councils of elders."

116. The Asia Foundation, supra note 81, p. 102.

117. See Coburn (2013); Swenson, supra note 3.

118. Rasooli, supra note 42. 
However, the formal justice institutions were amenable to the creation of a law that would regulate informal dispute-resolution bodies and thereby bring them under the control of the government. With a great deal of encouragement from the international community, the Draft Law on Dispute Resolution Shuras and Jirgas was created in September 2010. ${ }^{119}$ The draft law somewhat unrealistically sought to substantially limit how and when informal bodies could be used to resolve disputes. Still, it did not assuage the concerns of the human rights community and especially the women's rights institutions, which engaged in a successful effort to block its adoption.

More recent efforts at creating legislation that would integrate the informal system have been somewhat more successful at threading the needle. A draft Reconciliation Law has been finalized by the Ministry of Justice and has been pending approval. If it becomes law, the Huquq Department of the Ministry will be able to formally register outcomes in civil matters, after they ensure that the outcome does not violate the law. ${ }^{120}$ This would give customary dispute-resolution bodies an incentive to consider the boundaries of the law, and it provides the state with an avenue to gather data about these bodies and bring them into a holistic system.

Throughout this legislative debate, lawyers have maintained a practical and somewhat opportunistic approach to dealing with the informal system. While the AIBA would side with formal justice institutions in the debate on where development funds should be spent, it was also happy to work with the informal sector if there was a way it could receive some of the funds. ${ }^{121}$

AIBA's opportunism reflects that of its membership. In principle, most defence lawyers are staunch supporters of the formal justice system, yet, when it benefits their clients, they attempt - often successfully - to steer a case into the informal system where there is less chance that their clients will face incarceration. In criminal cases, this is typically achieved by convincing the victim to drop their complaint and then negotiating with the prosecution or judge. This negotiation with the formal justice actors will itself invoke the use of informal justice principles such as community harmony and harm reduction.

Anecdotally, many of these cases involve moral crimes and traffic accidents, which the formal justice sector deals with quite harshly and would in other jurisdictions be considered civil or private matters. ${ }^{122}$ For example, when a pedestrian is accidentally hit by a car, even if the driver stops and takes the victim to a hospital and acts in every way responsibly, the formal justice system may still arrest and bring criminal charges. This interferes with the ability of the driver to be able to redress the harm caused to the victim. A defence lawyer may try to convince the formal justice actors to release the driver and then resolve the matter either independently or using traditional dispute-resolution bodies. Similarly, if a defence lawyer can convince the families of a young couple who have run away together to drop their

119. Ministry of Justice, Draft National Policy on Relations between the Formal Justice System and Dispute Resolution Councils (2009) (on file with author).

120. This process of registration is already a practice in some provinces and districts, though it is neither standardized nor common. Conversations with Sandy Feinzig, June 2018.

121. See Yang, supra note 113.

122. E.g. a person convicted under Art. 559 of the 2017 Penal Code can be sentenced to five years' imprisonment for causing a traffic accident that leads to permanent disability or death. The only explanation of the mens rea involved is in Art. 556, which notes that, when the accident is caused by an intentional violation of traffic regulations, it is an aggravating circumstance. 
complaints and negotiate a marriage with the help of an informal body, and if the formal justice actors co-operate, the couple can avoid criminal charges of adultery (or escape from home $)^{123}$ or a degrading hymen examination.

Further, the addition of a defence lawyer provides a check on some of the power imbalances and lawlessness of the informal process. Well-trained defence lawyers consider themselves important instruments of the formal justice system who have a stake in its dominance and they intervene in the discussions to explain statutory laws to the informal body. Their legal opinions carry a great deal of weight and lawyers may return to formal venues in the event that an informal process veers into lawlessness.

This does not mean that there should be an insistence that every informal process include defence lawyers or that another informal justice project should be designed that encourages the inclusion of defence lawyers. Nor is it the case that only defence lawyers can pragmatically use the informal system. Shrewd judges and Huquq Department officials can also recommend that parties to a civil dispute attempt to resolve the matter outside the formal system. Rather, the ability of lawyers to navigate through and utilize both formal and informal structures illustrates that there is not only potential for an integrated system if the Reconciliation Law is passed, but that, under the right circumstances and with the right incentives, such a system is already being put to good use. ${ }^{124}$

\section{LEGAL EDUCATION}

One of the most glaring fractures in the legal landscape of Afghanistan is the legal-education system. The bifurcation between the Faculty of Law and Political Science and the Sharia Faculty was identified early on as a challenge for the development of a holistic legal system in Afghanistan. ${ }^{125}$ Several attempts have been made to bridge this gap, but the pace of progress has been glacial. Still, there is currently some momentum building behind efforts to finally make some progress and create greater unity in the education system and consequently the legal system as a whole.

Historically, the only legal education offered in Afghanistan was religious training in sharia. Madrasas provided secondary-level instruction on Islamic law and its graduates usually became judges. Beginning in the late nineteenth century, Afghanistan recognized the need for more uniform judicial procedures and, by the 1920s, the School of Administrators began training judicial administrators and personnel to make justice delivery more uniform. In 1938, Kabul University created the first Law Academy, offering a three-year course of study. It changed its name to the Faculty of Law and Political Science (FLPS) and added another year to its course of study in 1939. A Faculty of Islamic Law and Islamic Studies (Sharia Faculty) was not created until 1952. ${ }^{126}$

123. "Escape from home" or "running away from home" is a charge that does not exist in any law, but was often used by prosecutors. Several advisory opinions by the Supreme Court and directives by the Attorney General's Office have failed to clarify this situation beyond noting that the crime should be connected with an attempt at either adultery, fornication, or similar offence. For more information, see Wimpelmann (2017).

124. See Khan, supra note 9, p. 8.

125. See International Crisis Group (2003), p. 3; Weinbaum (1980), pp. 39-57.

126. Swenson \& Sugerman (2011), p. 133. 
Currently, both FLPS and Sharia Faculty students receive four-year undergraduate degrees and both faculties are divided into two departments. FLPS has a Judicial and Legal Sciences Department and a Political and Administrative Sciences Department. The Sharia Faculty is divided into the Qanoon and Fiqh Department and an Islamic Studies Department. At Kabul University, until just this year, only males were allowed to study at the Qanoon and Fiqh Department. ${ }^{127}$

The emphasis on what is studied varies greatly between the departments, with the Political and Administrative Sciences Department strongly emphasizing political science, history, and sociology, while the Islamic Studies Department concentrates on the study of hadiths, the Koran, Islamic history, etc. Both FLPS's Judicial and Legal Sciences Department and Sharia Faculty's Qanoon and Fiqh Department emphasize law courses but, even here, there is a substantial difference in what is emphasized. While there is some overlap, law students learn mostly about the Constitution, international laws, and national civil and criminal codes, and Sharia Faculty students mostly learn about jurisprudence, civil, and criminal law in Islam. The one common denominator in both the FLPS and the Sharia Faculty is a dearth of practical legal-education modules that prepare students for the practice of law after graduation, regardless of their area of specialization.

Since the 1960s and 1970s, there have been plans to merge the two separate faculties to create a legal-education system that produces legal professionals who can understand all of the law and legal traditions that make up the Afghan legal system. ${ }^{128}$ The US government supported another attempt in 2004-05, when now-President Ashraf Ghani was the Chancellor of Kabul University. Following a concerted political effort by traditionalists and members of the Sharia Faculty, this process failed. In 2008, an effort was launched to at least standardize legal education. Both faculties committed to develop a binding, shared "common core curriculum."129 Again, however, in 2009, the Sharia Faculty of Kabul University backed out of this arrangement and scuttled the effort for a unified curriculum. ${ }^{130}$

However, there are signs that the resistance to change is wearing down. In a 2015 survey of 120 legal professionals, academics, and students, 89\% agreed that legal education in Afghanistan is in need of fundamental reform. While the other $11 \%$ were undecided, no one disagreed. ${ }^{131}$ Similarly, $86 \%$ believed that a more unified approach would benefit the system, though a staunch $11 \%$ (mostly sharia professors) disputed this. Several Sharia Faculty graduates working as lawyers and prosecutors described their university education as a betrayal. ${ }^{132}$ FLPS graduates complained that only a very small percentage of those who pass the entrance exam to join the judiciary are graduates of FLPS. They regretted that their understanding of Fiqh is inadequate to meet the levels demanded by the judiciary. ${ }^{133}$

127. The Asia Foundation (2015), p. 32.

128. Similar to the 2004 Constitution, the 1964 Constitution creates a complex legal landscape.

129. There was agreement to include 11 core subjects: (1) Introduction to Law; (2) Constitutional Law; (3) Human Rights; (4) Principles of Fiqh; (5) Criminal Law; (6) Criminal Procedure; (7) Civil Law/Civil Code; (8) Civil Procedure; (9) Commercial Law; (10) Commercial Procedure; and (11) Professional Responsibility and Ethics for Lawyers. A new textbook on each subject was to be drafted by a committee of senior professors for use nationwide.

130. Swenson \& Sugerman, supra note 126, p. 138.

131. The Asia Foundation, supra note 127, p. 13.

132. Ibid.

133. Ibid. 
Under the Ghani administration, the Ministry of Higher Education has been more open to encouraging change at the faculties. ${ }^{134}$ In 2017, the FLPS of Kabul University was forced to create separate curricula for the Judicial and Legal Sciences Department and the Political and Administrative Sciences Department. This creates space for both departments to add more subject specific courses. Meanwhile, the Sharia Faculty was forced to incorporate women into the Qanoon and Fiqh Department.

This is an important step if there is ever going to be anything resembling a unified department or common core curriculum. Even with a common core curriculum, some of the classes would have to be taught by Sharia Faculty professors who would need to be fully supportive of women taking these classes. There are those who are fine with women taking these classes so long as they are separated from the men. However, this creates a resource shortage that then hinders the ability to provide separate but equal education. It is a matter that has seen surprisingly little attention from women's rights organizations.

Other avenues for change are also being considered more seriously. The most important of these are simply more skills-based courses such as research and writing and more experiential learning opportunities such as legal clinics that allow students to be exposed to the realities of the state of the Afghan legal system as early as possible.

\section{CONCLUSION}

Development is hard and designing and implementing a useful rule-of-law development project requires, among other things, a wide perspective and inspiration. Academics can summarize the rule of law to a sovereign bound by the law and citizens whose lives and property are protected from infringement and assault by other citizens. ${ }^{135}$ They may expand the discussion to label the elements of the rule of law or to describe an ends-based definition. ${ }^{136}$ For a development professional like myself, this literature can be helpful to put one's work into context, but it is difficult to measure progress using these broad categories as metrics. Rather than being aspirational, in Afghanistan, a list of the elements of the rule of law can be daunting to the point of paralysis, considering the reality of the ongoing conflict, the political pandemonium, and the heavy involvement of the international community. Also, much of the literature on rule-of-law development in Afghanistan is excellent at identifying failures but less adept at accurately describing the reasons for those failures or presenting workable solutions.

On the other hand, with the proliferation of results-based project management and monitoring and evaluation tools that count every meeting and measure every training, it can be difficult to discern a broader purpose in one's work. These are necessary systems that help with creating day-to-day work plans, reporting to donor organizations, and assuaging headquarters. However, these systems are neither inspirational nor able to capture a wider perspective beyond almost context-free impact statements such as "increased trust in the formal justice system" or "increased access to justice for vulnerable people" that could be

134. Conversations with Dr Munir Ahmad Aziz, Legal Education Advocacy Officer at The Asia Foundation, December 2017.

135. Bedner (2010), p. 50.

136. Ibid.; Belton (2005). 
used in almost any country. Further, mid-term and final project evaluations (even when they are done on time) may help donors and headquarters offices make course corrections, but present information that is mostly obvious to field-based professionals, such as repeated admonitions about the need for sustainability.

There are also several imperative matters, such as the peace process, military campaign, counter-narcotics, elections, etc., that are important frameworks or can serve as the basic rational for funding but that are too far outside the scope of a rule-of-law development project to serve as inspiration. One exception to this is human rights, which is the background with which I entered development and serves as the inspiration for many service-delivery projects, including some of the first projects I worked on. However, as discussed above, the overlap between rule of law and human rights is complicated, and the development of a dynamic and distinct legal system is sometimes in conflict with the rigidity and universality of the human rights context.

Therefore, personally, I find most of my inspiration in the notion that Afghanistan may be able to build a legal system that embraces and manages its normative pluralism. Afghan professionals and citizens are slowly developing a system that could, one day, effectively and coherently incorporate constitutional principles, state laws, local customs, Islamic jurisprudence, and international conventions to deliver dispute resolution and justice in a unified rather than a unitary system. This may be criticized as unabashedly optimistic but, as noted above, development is hard, and a bit of optimism is an important element when looking for inspiration.

\section{REFERENCES}

Ahmed, Faiz (2005) "Judicial Reform in Afghanistan: A Case Study in the New Criminal Procedure Code." 29 Hastings International and Comparative Law Review 93-134.

Armytage, Livingston (2007) "Justice in Afghanistan: Rebuilding Judicial Competence after a Generation of War." 67 Heidelberg Journal of International Law 185-210.

Bedner, Adriaan (2010) "An Elementary Approach to the Rule of Law." 2 Hague Journal on the Rule of Law 48-70.

Belton, Rachel K. (2005) "Competing Definitions of the Rule of Law: Implications for Practitioners," https://carnegieendowment.org/files/CP55.Belton.FINAL.pdf (accessed 11 August 2018).

Brown, Jonathan (2017) "Stoning and Hand Cutting-Understanding the Hudud and the Shariah in Islam," https://yaqeeninstitute.org/wp-content/uploads/2017/01/Stoning-and-Hand-CuttingUnderstanding-the-Hudud-and-the-Shariah-in-Islam-1.pdf (accessed 11 August 2018).

Checchi and Company Consulting, Inc. (2011) "Rule of Law Stabilization Program-Informal Component," Final Report, November 2011.

Choudhury, Nafay (2017) "Revisiting Critical Legal Pluralism: Normative Contestations in the Afghan Courtroom." 4 Asian Journal of Law and Society 229-55.

Coburn, Noah (2013) "Informal Justice and the International Community in Afghanistan," https:// www.usip.org/sites/default/files/PW84-Informal\%20Justice\%20and\%20the\%20International\% 20Community\%20in\%20Afghanistan.pdf (accessed 11 August 2018).

Cook-Miligan, Dana (2013) "What Is Really So Bad About a Different Rule of Law: The Afghan Legal System Re-Analysed." 41 Hastings Constitutional Law Quarterly 205-34.

Daxner, Michael (2011) "Legal Pluralism-Decentralization of the Rule of Law?," https://www. afghanistan-analysts.org/guest-blog-legal-pluralism-decentralization-of-the-rule-of-law/ (accessed 11 August 2018). 
Day, Dominique, \& Siavash Rahbari (2017) “Legal Aid Assessment and Roadmap," https://asiafoundation. org/wp-content/uploads/2017/05/AG_Legal-Aid-Assessment-and-Roadmap.pdf (accessed 11 August 2018).

De Lauri, Antonio (2010) "Legal Reconstruction in Afghanistan: Rule of Law, Injustice, and Judicial Mediation," www.juragentium.org/topics/wlgo/en/delauri.htm (accessed 11 August 2018).

De Lauri, Antonio (2013) "Law in Afghanistan: A Critique of Post-2001 Reconstruction." 6 Journal of Critical Globalisation Studies 4-29.

Government of the Islamic Republic of Afghanistan (2005) "Justice for All: A Comprehensive Needs Analysis for Justice in Afghanistan," https://www.cmi.no/pdf/?file=/afghanistan/doc/Justice\%20for \%20all\%20MOJ\%20Afgh.pdf (accessed 11 August 2018).

Hartmann, Michael E., \& Agnieszka Klonowiecka-Milart (2011) "Lost in Translation: Legal Transplants without Consensus-Based Adaptation," in W. Mason, ed., The Rule of Law in Afghanistan: Missing in Action, New York: Cambridge University Press, 266-98.

Human Rights Watch (2013) “Afghanistan: Reject Proposal to Restore Stoning," https://www.hrw.org/ news/2013/11/25/afghanistan-reject-proposal-restore-stoning (accessed 11 August 2018).

Idaho Statutes (2018) "18-6601, added 1972, chapter 336, section 1," https://legislature.idaho.gov/ statutesrules/idstat/title18/t18ch66/sect18-6601/ (accessed 11 August 2018).

Imperial Ottoman Penal Code (1913) "The Imperial Ottoman Penal Code: A Translation from the Turkish Text," https://ia902704.us.archive.org/7/items/TheImperialOttomanPenalCode/ OttomanPenalCode.pdf (accessed 11 August 2018).

Integrity Watch (2018) "Afghanistan's Fight against Corruption Has Stalled due to Lack of Independent Anti-Corruption Institutions," https://iwaweb.org/integrity-watch-the-fall-of-afghanistan-oncorruption-perceptions-index-indicates-the-governments-inability-in-the-fight-against-corruption/ (accessed 11 August 2018).

International Crisis Group (2003) "Afghanistan: Judicial Reform and Transitional Justice," http:// unpan1.un.org/intradoc/groups/public/documents/APCITY/UNPAN016653.pdf (accessed 11 August 2018).

International Crisis Group (2010) "Reforming Afghanistan's Broken Judiciary," https:// d2071andvip0wj.cloudfront.net/195-reforming-afghanistan-s-broken-judiciary.pdf (accessed 11 August 2018).

Jupp, John (2013) "Legal Transplants as Solutions for Post-Intervention Criminal Law Reform: Afghanistan's Interim Criminal Procedure Code 2004." 61 The American Journal of Comparative Law 51-92.

Kamali, Mohammad H. (1998) "Punishment in Islamic Law: A Critique of the Hudud Bill of Kelantan, Malaysia." 13 Arab Law Quarterly 203-34.

Kessler, Glenn, \& Michelle Y. H. Lee (2016) "Fact-Checking the Clinton and Trump Speeches after Orlando," https://www.washingtonpost.com/news/fact-checker/wp/2016/06/14/fact-checking-theclinton-and-trump-speeches-after-orlando/ (accessed 11 August 2018).

Khan, Hamid M. (2015) "Islamic Law, Customary Law, and Afghan Informal Justice," https://www. usip.org/sites/default/files/SR363_Islamic_Law_Customary_Law_and_Afghan_Informal_Justice. pdf (accessed 11 August 2018).

Meeting Minutes (2017) "Budget for Foreign Trade and Development Cooperation 2018," https://zoek. officielebekendmakingen.nl/h-tk-20172018-25-3.html (accessed 11 August 2018).

Ministry of Justice of the Islamic Republic of Afghanistan (2018) "Department of Huquq," http://moj. gov.af/en/page/7943/7944/7948 (accessed 11 August 2018).

Mufihun (2018) "Sahih al-Bukhari Book 89 Hadith 292," https://muflihun.com/bukhari/89/292 (accessed 11 August 2018).

Office of the United Nations High Commissioner for Human Rights (2018) "Framework for Communications-IV 3: Intersection of Freedom of Religion or Belief with Other Human Rights," https://www.ohchr.org/EN/Issues/FreedomReligion/Pages/IstandardsIV3.aspx $\quad$ (accessed 11 August 2018).

Otto, Jan M. (2008) Sharia and National Law in Muslim Countries: Tensions and Opportunities for Dutch and EU Foreign Policy, Leiden: Leiden University Press. 
Oxford Islamic Studies Online (2018) "Habb," http://www.oxfordislamicstudies.com/article/opr/t125/ e757 (accessed 11 August 2018).

Perathoner, Michela, ed. (2011) "Italy and The Rebirth of Afghanistan's Justice System," https://www. slideshare.net/IDCOAFGHANISTAN/italy-and-the-rebirth-of-the-afghan-justice-system (accessed 11 August 2018).

Rabb, Intisar A. (2010) "Islamic Legal Maxims as Substantive Canons of Construction: HududAvoidance in Cases of Doubt." 17 Islamic Law and Society 63-125.

Rzehak, Lutz (2011) "Doing Pashto: Pashtunwali as the Ideal of Honourable Behaviour and Tribal Life among the Pashtuns," https://www.afghanistan-analysts.org/wp-content/uploads/downloads/ 2012/10/20110321LR-Pashtunwali-FINAL.pdf (accessed 11 August 2018).

Smith, Jennifer, Natalie Rae, \& Shabir A. Kamawal (2011) "The Right to Counsel as a Safeguard of Justice in Afghanistan: The Contribution of the International Legal Foundation." 92 International Review of the Red Cross 951-66.

Supreme Court of the Islamic Republic of Afghanistan (2012) "Special Bulletin of the Supreme Court," http://supremecourt.gov.af/Content/files/bulletin_Vol15.pdf (accessed 11 August 2018).

Swenson, Geoffrey (2017) "Why U.S. Efforts to Promote Rule of Law in Afghanistan Failed." 42 International Security 114-51.

Swenson, Geoffrey, \& Eli Sugerman (2011) "Building the Rule of Law in Afghanistan: The Importance of Legal Education." 3 Hague Journal on the Rule of Law 130-46.

Taylor, Veronica L. (2008) "Building Capacity of Legal Professionals in Afghanistan: 2008 Survey," http://www.idlo.org/Documents/Report_Afghanistan_Taylor_2008.pdf (accessed 11 August 2018).

The Asia Foundation (2015) "An Assessment of Increasing Access to Justice for Family Law Clients and Strengthening the Capacity of Civil Society and Young Lawyers to Protect Human Rights in Afghanistan Project," 25 June 2015 (on file with the author).

The Asia Foundation (2017) "Afghanistan in 2017: A Survey of the Afghan People," https:// asiafoundation.org/wp-content/uploads/2017/11/2017_AfghanSurvey_report.pdf (accessed 11 August 2018).

The Asia Foundation (2018) "Resources," https://asiafoundation.org/where-we-work/afghanistan/ survey/ (accessed 11 August 2018).

Transparency International Secretariat (2018) "New Report Finds Afghan Government's AntiCorruption Efforts Insufficient for its SDG Commitments," https://www.transparency.org/news/ pressrelease/new_report_finds_afghan_governments_anti_corruption_efforts_insufficient (accessed 11 August 2018).

UN Assistance Mission in Afghanistan (2018) "Midyear Update on the Protection of Civilians in Armed Conflict: 1 January to 30 June 2018," https://unama.unmissions.org/sites/default/files/ unama_poc_midyear_update_2018_15_july_english.pdf (accessed 11 August 2018).

UN Development Programme (2013) "Justice and Human Rights in Afghanistan (JHRA) Project: 2013 Second Quarterly Project Progress Report," http://www.undp.org/content/dam/afghanistan/docs/ crisisprev/JHRA/JHRA-2QPR-2013.pdf (accessed 11 August 2018).

UN General Assembly (1948) "Universal Declaration of Human Rights," 217 (III) A, http://www.un. org/en/universal-declaration-human-rights/ (accessed 11 August 2018).

UN General Assembly (1966) "International Covenant on Civil and Political Rights," in Treaty Series, 999, New York: United Nations, 171-86.

UN General Assembly (2006) "The Situation in Afghanistan and its Implications for Peace and Security: Report of the Secretary-General," A/61/326, http://www.un.org/en/ga/search/view_doc. asp?symbol=S/2006/727 (accessed 11 August 2018).

UN News (2012) "Group of UN Experts Urge Governments to Repeal Laws That Criminalize Adultery," https://news.un.org/en/story/2012/10/423892-group-un-experts-urge-governments-repeallaws-criminalize-adultery (accessed 11 August 2018).

US Department of Defence (2012) "Report on Progress toward Security and Stability in Afghanistan," https://www.defence.gov/Portals/1/Documents/pubs/1230_Report_final.pdf (accessed 11 August 2018). 
USAID (2005) "Afghanistan Rule of Law Project: Field Study of Informal and Customary Justice in Afghanistan and Recommendations on Improving Access to Justice and Relations between Formal Courts and Informal Bodies," http://pdf.usaid.gov/pdf_docs/Pnadf590.pdf (accessed 11 August 2018).

USAID (2012) "Rule of Law Stabilization-Formal Sector Component Program Evaluation: Final Report," http://pdf.usaid.gov/pdf_docs/pdacu496.pdf (accessed 11 August 2018).

Wafa, Abdul W., \& David Rohde (2006) "Kabul Judge Rejects Calls to End Trial of Christian Convert," http://www.nytimes.com/2006/03/24/world/asia/kabul-judge-rejects-calls-to-end-trial-ofchristian-convert.html (accessed 11 August 2018).

Wardak, Ali (2004) "Building a Post-War Justice System in Afghanistan." 41 Crime, Law \& Social Change 319-41.

Weinbaum, M. G. (1980) "Legal Elites in Afghan Society." 12 International Journal of Middle East Studies 39-57.

Wimpelmann, Torunn (2017) "Adultery, Rape, and Escaping the House: The Protection and Policing of Female Sexuality in Afghanistan," https://www.cmi.no/publications/6404-adultery-rape-andescaping-the-house (accessed 11 August 2018).

Wyler, Liana S., \& Kenneth Katzman (2010) "Afghanistan: U.S. Rule of Law and Justice Sector Assistance," https://fas.org/sgp/crs/row/R41484.pdf (accessed 11 August 2018).

Yang, Xinxin (2013) "Support to Local Justice in Kapisa and Surobi Final Project Report," IDLO, January 2013.

Yassari, Nadjma, \& Mohammad H. Saboory(2010) "Sharia and National Law in Afghanistan," http:// www.juragentium.org/topics/islam/en/yassari.htm (accessed 11 August 2018).

Yorke, Jon, \& Amna Nazir (2017) "Draft General Comment on Article 6 of the International Covenant on Civil and Political Rights-the Right to Life," http://www.open-access.bcu.ac.uk/5614/ (accessed 11 August 2018).

Zarinebaf, Fariba (1998) "Women and the Public Eye in Eighteenth Century Istanbul," in G. R. G. Hambly, ed., Women in the Medieval Islamic World: Power, Patronage, and Piety, New York: St. Martin's Press, 301-24. 